\title{
Obesity: locating social responsibility in the context of evolving norms
}

\author{
by Manning, L. and Kelly, J.
}

Copyright, publisher and additional information: .This is the authors' accepted manuscript. The published version is available via Inderscience Publishers.

Please refer to any applicable terms of use of the publisher.

DOI: https://doi.org/10.1504/IJISD.2020.104241 


\title{
Obesity: Locating social responsibility in the context of evolving norms
}

\section{MANNING, L' ${ }^{1}$ AND KELLY, J. ${ }^{2}$}

\begin{abstract}
Most countries have experienced a significant increase in the incidence of obesity in their general population over the last twenty years. Indeed, the condition is now so common, commentators conclude that obesity has become normalized and no longer attracts social opprobrium. The prevalence of obesity and related morbidities when the condition is normalized places it beyond the scope of conventional government interventions. In this context, the UK government adopted a multisector approach in England by announcing in 2011 that its policy on obesity would be predicated on the importance of individuals' responsibility for their condition, while also facilitating food and drink industry responsibilities to its customers. This paper considers the social trend towards the normalization of obesity as a lens to discuss government's role in supporting businesses to demonstrate and act upon their social responsibilities. Furthermore to question whether individual and social responsibility are theoretically robust terms for policy purposes, particularly in the case of obesity where the condition is now increasingly accepted as being the norm.
\end{abstract}

\section{Keywords}

Obesity, social, corporate, policy, responsibility, norm,

\section{Introduction}

Consumers in the United Kingdom (UK), as elsewhere, have benefitted from globalization and fierce competition among food retailers in terms of all year around product choice, and lower food prices (Manning and Baines 2004). At the same time social developments such as smaller households, increasing numbers of women joining the workforce, and easier access to processed food have been implicated in changing dietary patterns at both individual and family levels (Manning, 2016). Others, such as Appelhans et al. (2012), suggest that the relative affordability of energy dense foods (high in sugar, fats and salt) compared to nutrient rich foods

\footnotetext{
${ }^{1}$ Harper Adams University, Newport, Shropshire, TF10 8NB

${ }^{2}$ Aston Business School, Aston University, Birmingham, UK B4 7ET
} 
such as fruit and vegetables, are implicated in socioeconomic disparities in the incidence of diet related malnutrition (DRM), often presented as obesity. Thus suggesting poor nutrition (both under and over consumption of calories) is a particular issue for low-income households. However, this is just one in a multifaceted set of factors that contribute to the growth of an obesogenic environment (Lake and Townshend 2006, Lake et al. 2010, Manning et al. 2016). Knowledge and understanding of the concept of an obesogenic environment is an accumulation of research conclusions that suggest individual agency is not the only factor in the increase of the incidence of obesity. Identification of the increased availability of energy dense food products and food opportunities outside the home, the decline of manual employment, the structure of the built environment and changes to transport point to the limitations of the perspective of the failed individual prone to gluttony and or sloth that prevails in common sense discourses about the cause and indeed the cure of obesity (Prentice and Jebb 1995). Despite the connections between prosperity and obesity in some cultures, in contemporary Britain, as elsewhere, the condition is linked to the incidence of a number of serious comorbidities including those that are potentially life shortening, or life changing.

Not withstanding considerable shifts in the role and purpose of governments, even in times of neoliberalism, governments retain residue responsibilities to safeguard their citizens 'wellbeing'. In the case of the UK, policy on obesity has focused on the most vulnerable, such as young children, whilst promoting individual responsibility by improving the public knowledge of what constitutes a healthy lifestyle and a balanced diet. In 2011 the UK Government worked towards responsibility activities by signing up to the Public Health Responsibility Deal (PHRD) and to promote 'healthier choices' introducing a voluntary agreement in England with the food and drink industry (FDI) to enhance their social and to provide their customers with greater knowledge of the nutritional content of their food. Yet, this approach has attracted 
considerable criticism; particularly concerning the voluntary nature of the PHRD, the role of industry in setting the targets for reduction in salt, fats and sugar in foodstuff and determined advertising, particular directed towards children. (Hasham et al. 2012). Moreover, the emphasis on individual responsibility is particularly problematic; using insights from the concept of the obesogenic environment, it suggests that individual agency has limited capacity to resist powerful society wide drivers, such as food advertising, the availability of food and how excess food consumption has become embedded in much of social and family activities. Also controversial is the concept of social responsibility (SR). Much of the seminal literature on SR tends towards discussing the lack of a parsimonious definition, the challenges of implementation and its lack of any generalizable capacity because of the intense normative elements in the academic literature and the diversity of how companies balance their responsibilities to their shareowners and to their other stakeholders. In this paper we focus on the question as to whether governments can act as a nexus for the development of companies' SR strategies and operations. Rayman-Bacchus and Walsh (2016) explored the notion of conceptualizing responsibility as a nexus, not only with regard to the interaction of government, business, and multilateral organizations, but also encompassing the interdependence of informal and formal (tangible and intangible) associations. They argue that whilst these interactions drive development they can also through integration of different actors, develop structures that are based on accumulated practice, resist change and contain ever-present conflicts of interest. Further such interactions are often dynamic and reciprocal between actors underpinning what it is for a corporate to be responsible. Using the policy problematic of the normalization of obesity, the paper discusses first a number of the drivers that have reduced social stigma of the condition and second, considers whether government driven initiatives can foster SR in the FDI around the PHRD to question what it is to be socially responsible at individual, corporate and governmental levels. 


\section{Social norms and health costs}

Over the last twenty years with the incidence of obesity in the general population increasing, as a result the condition has become increasingly socially normalized. Until 1980, less than ten per cent of the population was obese in OECD countries (OEDC, 2014). The report states that nearly thirty-five years later, across the OECD, eighteen per cent of the adult population is defined as obese. This varies between countries with more than one in three adults in Mexico, New Zealand and the United States (US), and more than one in four in Australia, Canada, Chile and Hungary being defined as obese (OECD, 2014). Rates of obesity more than doubled in 15 years in urban West Africa (Ellulu et al. 2014 citing Abubakari et al. 2008). Obesity is estimated to be responsible for $1 \%$ to $3 \%$ of total health expenditure in most countries (5\% to $10 \%$ in the US) and costs will rise rapidly in coming years as obesity-related diseases set in (OECD, 2014). DRM, which includes obesity, affected 3 million people in the UK in 2007 costing in excess of $£ 13 \mathrm{bn}$ and corresponding to about $10 \%$ of the expenditure on health and social care in that year (Elia and Stratton, 2009, Manning et al. 2016). In the European Union (EU) around 20 million people are affected by DRM, costing EU governments up to $€ 120$ billion annually (Freijer et al. 2012). This cost to a social health service free at the point of use is only set to increase in a time of austerity with a stark focus on public spending against a backdrop of nation states in the EU struggling to service public debt.

Wang et al. (2014) define social norms as rules that guide individual behavior in interactions with others. Higgs (2015:38) considers social norms as being "implicit codes of conduct that provide a guide to appropriate action". Social norms focus on what is considered socially acceptable in terms of body image and consumption behavior, for example when it is acceptable to eat (such as in public or frequency of eating, sometimes described as continuous 
grazing) types of food eaten, and acceptable portion size. Studies have been undertaken not only in the field of social norms associated with food and drink, but also other social behaviors such as alcohol consumption (Lally et al. 2011). Kemper et al. (1994:117) identified that there were cultural differences between subjects and their beliefs and perceptions about body size norms explaining in part why heavier body weights persist in some cultural groups more than others.

Although the importance of social norms influencing health behavior is widely recognized, understanding of their impact on obesity is limited especially if it is considered that the status of being obese is somehow "contagious" (Wang et al. 2014). The authors caution that it is important to reflect that social norm is one in a number of social and contextual factors, operating at micro and macro levels, that impact on the growing proportion of the population that is considered obese. Many social factors may influence self-perceptions of body weight, including the media, public health messages, and scholastic content disseminated in the popular media. Indeed, repeated media stories on overweight status might actually contribute to the perception that overweight has become the norm (Burke et al. 2010). The Burke et al. study showed that people were less likely to desire weight loss irrespective of their overall weight status and thus less inclined to consider dieting or increasing physical activity. This, the authors conclude, drives a general sense of complacency and may influence the success of public health campaigns. Lally et al. (2011) propose that individuals are influenced by multiple social norms e.g. young adolescents can be influenced by both peer norms of what is deemed acceptable as well as parental norms. Further the agent of influence might well be perceived social norms (how individuals believe others are behaving) rather than the actual behavior that is being enacted. Wang et al. (2014) in their study on school children found that social norm was influenced by gender showing that social norm had less impact stimulating weight reduction among girls and greater impact promoting weight increase among boys. The authors suggest, 
primarily due to dietary habits, physical activity level and lifestyle, that girls may have more challenges than boys to lose weight arguing that consumption of energy dense foods was influenced more by visual cues and palatability than a social norm of what was the appropriate level of fruit and vegetables to consume. Jackson et al. (2015) in their research on normal weight, overweight and obese adolescents found that of normal-weight subjects $83 \%$ of boys and $84 \%$ of girls correctly identified themselves as 'about the right weight'. In this group overestimation was uncommon. However, $4 \%$ of boys, and $11 \%$ of girls of normal weight subjects identified themselves as 'too heavy'. When considering individuals with a body mass index (BMI) that would place them in an overweight or obese range, $53 \%$ of boys, and $68 \%$ of girls (average 60\%) correctly identified themselves as 'too heavy', while 39\% (47\% of boys, $32 \%$ of girls) underestimated, identifying themselves as 'about the right weight' or 'too light'. This study shows in adolescent boys the greater weight norm also identified by Wang et al. (2014).

However the context is not just at individual level. The influence of community also plays a part. Goodman et al. (2014) highlight that in order to define community health and identify the stakeholders and agents that play a role in developing a community health policy the concept of what is a community needs to be defined (Manning et al. 2016). MacQueen et al. (2001) suggest there is a limitation not only describing what a community is, but also the perceptions of different potential collaborators of what community is in practice. This can undermine the ability to assess how community collaborations actually play a role in achieving public health objectives (Goodman et al. 2014). Lebel (2003) consider that rather than the biomedical approach to assessing health there should instead be an 'ecosystem approach' where the influences of community, environment and the local, national and global economy on health is considered (Manning, 2016; Manning et al. 2016). Thus, from a public health policy 
perspective, access to, and the take up of, higher nutrition foods by disadvantaged neighborhoods, as well as society as a whole needs, to be considered a policy priority for government, although there are deep disagreements on how this should be achieved in practice and whether it is could ever be acceptable for the government to venture into directing citizens towards what food to eat and to police the consumption of certain foodstuffs (Manning et al. 2016).

\section{Public health initiatives connected with obesity}

The food environment can improve nutrition and reduce obesity through a three-fold strategy: improving the image of healthy food and making unhealthy food less attractive, altering relative food prices, and shifting exposure to food, (Frieden et al. 2010). This predicates the question of what is the role of the FDI in determining what is healthy and unhealthy especially if there is a different profit differential between energy dense and nutrient rich foods. Public policy strategies that are of value in nudging the public in terms of their decisions include: tax policies, pricing strategies, influencing exposure and access to healthy food, zoning restrictions to limit the density of fast-food restaurants, voluntary advertisement restrictions, banning certain food advertisements especially those aimed at children at certain times, counteradvertising, improving the image of healthy foods, and eating out (Frieden et al. 2010, Manning et al. 2016). Global examples of obesity associated public health initiatives have been synthesized (Table 1).

\section{Take in Table 1}

Despite widespread recognition of the incidence of obesity, in no country has this been reversed purely by public health measures (Panjwani and Caraher, 2014). The 2011 UK government's PHRD set targets and priorities and academics, voluntary organizations and business partners, made voluntary pledges contributing to the strategy in five areas: food, alcohol, health at work, 
physical activity, and behavior change (OEDC, 2014; Panjwani and Caraher 2014; Bryden et al. 2013). The PHRD has been described as a public-private partnership developed to capture the potential for private organizations, National Health Service (NHS) Trusts and local authorities to make a significant contribution to improving public health by helping create an enabling environment and legitimizing industry involvement in the design of policy measures (Panjwani and Caraher 2014; Petticrew et al. 2013). The relevant commitments address improving people's health, encouraging and enabling people to adopt a healthier diet, encouraging and assisting people to become more physically active and actively supporting organizational workforces to lead healthier lives. Frieden et al. (2010) also identify policy strategies for increasing physical activity including increasing active transportation and recreation, reducing sedentary behavior, and improving physical activity programs aimed at children.

\section{Take in Table 1}

Aylott et al. (2008) considered the Foresight Report (2007) on obesity and the implications for local government. They identified four local government areas of responsibility in tackling the problem of obesity namely, planning, children's services, adult social care and parks and leisure showing some connectivity with the PHRD. Petticrew et al. (2013) argue that each of the pledges can be considered as a public policy intervention with different potential degrees of impact. Further that if such pledges are not time-bound then success or failure cannot be easily evaluated. Therefore such pledges need to be SMART (specific, measurable, attainable, relevant and time-bound) not doing so will mean that pledges are not focused sufficiently on meaningful health outcomes (Panjwani and Caraher, 2014). Bryden et al. (2013) assert that targets for businesses need to be clearly defined, realistic, but stretching, to achieve real change. Panjwani and Caraher (2014) distinguish between interventions that focus solely on individual 
choice and those that are complemented by public health policy especially where such policy, as previously described by Lebel (2003) takes an ecological approach recognizing that choice is made within the confines of a larger obesogenic environment.

It has been suggested that PHRD initiatives can produce change more quickly than through regulation. This could be for a variety of reasons including lower transaction costs in private business (Panjwani and Caraher, 2014). Benabou and Tirole (2010) highlight that due to their market orientation and lower levels of bureaucracy, corporations often have lower transaction costs than governments. Therefore there are economic drivers that influence governments to avoid regulation, and use policy initiatives implemented through food manufacturers and retailers instead (Manning, 2016). The UK Department of Health report on the PHRD (DH, 2011) identifies three central elements: core commitments, collective and individual pledges, and supporting pledges. Individual businesses can sign up to the core commitments, collective agreed action and individual organizational pledges. Table 2 contains the core commitments and the supporting pledges that have been developed. There were fifteen different food pledges that organizations signed up to and these have been detailed by pledge with the number of signatories (Table 3), demonstrating the limited formal engagement by the FDI. However it could be argued with the specific organizations that have signed up to the pledges the impact will cascade through their diverse supply chains to reach a far greater number of organizations.

\section{Take in Tables 2 and 3}

As an example the signatories to $\mathrm{F} 4$ Calorie reduction have been categorized by type retailer, manufacturer, food service etc. to demonstrate this cascade effect (Table 4). The headline frequency of pledges in this category were: catering, food service and facilities management (12), retailers (8), and soft drinks manufacturers (8). Manufacturing categories that were poorly represented in this calorie reduction category include chilled food products manufacture, and 
dairy products manufacture. As part of this research the pledges made by food service companies have been analyzed (Table 5). They highlight a variance with the majority of those who have been reviewed ( $81 \%$ ) having pledged to the "non-use of artificial trans fats"; $56 \%$ pledged to "reduce salt" and $44 \%$ pledged to "out of house energy labeling". Only a quarter signed up for the fruit and vegetable pledge and $11 \%$ to reducing saturated fats.

\section{Take in Tables 4 and 5}

Bryden et al. (2013) highlight similar public-private initiatives such as the Voluntary Initiative (Agriculture), Voluntary Agreement on Advertising and Labeling (Tobacco), and the Climate Change Levy Agreements (Energy). They determine that there are three categories of voluntary agreements that:

(i) Are completely voluntary where businesses have a totally free choice on whether to join and there are no sanctions for non-compliance.

(ii) Use the threat of future regulations or taxes as a motivation to participate, and

(iii) Are implemented in conjunction with an existing tax policy or strict regulations (Bryden et al. 2013:191).

They argue that the PHRD is a hybrid of the first two approaches, but without specific sanctions for non-compliance and credible monitoring it is likely to be ineffective. Public/private partnerships within these agreements can prove difficult when there is a disparity in objectives e.g. market drive to sell more versus a public perspective to eat less however, criticisms of the PHRD approach include that governments are abdicating responsibility for public health to the private sector rather than adopt more evidence based approaches; and that industry has a conflict to address in terms of maintaining shareholder value in the face of delivering to policy objectives (Panjwani and Caraher, 2014). Further Panjwani and Caraher (2014) conclude that "it is the collaborative, voluntary working practices of the approach that have undermined its 
potential as a public health policy tool and hindered its ability to deliver at a population level ... [and] the resulting distraction of objectives and preclusion of evaluation is likely to result in a significant public health opportunity cost." The interrelationship of meeting shareholder expectations and also demonstrating social responsibility is discussed in the next section of the paper.

\section{Social responsibility - Business}

Organizations have a responsibility to the consumers they serve. Being a responsible corporation is challenging within a free market paradigm (Amaeshi et al. 2007). For multinational corporations (MNCs) the people they serve can be remote, characterless and compartmentalized as a demographic market segment (Manning, 2016). It is crucial that MNCs deliver value to all stakeholders. Indeed, value products are often seen as low cost food choices, where the quality of the product is minimized to meet cost targets to such a point that the micronutrient value is potentially compromised (Manning, 2016). Friedman (1962:133) states "there is one and only one social responsibility of business - to use its resources and engage in activities designed to increase its profits". The concept of stakeholder theory promotes that the premium role of organizations is to be focused on profit and shareholder value and that public good is served by allowing organizations to operate with minimum regulation in order for them to provide livelihoods, tax return and so forth. Thus corporate social responsibility (CSR) strategies cannot be pursued to the detriment of shareholder return (Heath and Norman, 2004).

In the UK especially, a shift in patterns of accountability from public policy management has led to a congested state with multiple levels of actors including corporate organizations (Herrick, 2009). Positively, this could drive an entrepreneurial approach to health, but the weakness in this situation is a question over the legitimacy and authority of public health policy 
when the FDI itself is involved in determining solutions (Manning et al. 2016). "Health" as an attribute and the associated cultural have the potential to deliver brand value (Herrick, 2009) Whilst understanding that over consumption can cause health problems, free market thinking supports consumers being free to choose to what and when to consume. Elected governments have a responsibility for food security and public health and education, as do the corporations that formulate, process, distribute and sell especially energy dense foods (Manning, 2016). Further, the responsibility of how to deliver value to all consumers sits with the executives that run companies and their supply base. Spence and Bourlakis (2009) argued that the UK Government discourse on CSR focused on voluntary practices, as with the examples previously described, rather than government intervention. Therefore, corporate responsibility (CR) i.e. the voluntary actions that an organization can take, over and above compliance with minimum legal requirements, will address both its own competitive interests and also the interests of the wider society. Therefore organizations are seen as being an integral part of society and having the potential to make a positive contribution to social goals and aspirations (Jones et al. 2005). However, as with the work of Stigliz (2006) it can be postulated that in an unconstrained market economy, private incentives are not always aligned and the pursuit of organizational selfinterest itself will not deliver social benefits, rather that such initiatives can be used to influence consumers and differentiate products (Becker-Olsen et al., 2006). Herrick (2009) suggests that CSR strategies have had a two-fold approach to health: a focus on the logic of calorie balance (energy intake in vs. energy expended) and the linking of this to informed choice. The food service sector, through an SR agenda, has initiated many healthy eating campaigns under the CSR "umbrella" to satisfy customer demands and for healthful eating environments (Lee et al. 2014). In turn this has improved perceptions of the organization. The concept of informed choice and individuals being in a position to act on the basis is an important element of the regulatory: corporate: individual interaction. 


\section{Individual responsibility and the concept of vulnerability}

Foresight (2007:5) states that: "People in the UK today don't have less willpower and are not more gluttonous than previous generations. Nor is their biology significantly different to that of their forefathers. Society, however, has radically altered over the past five decades, with major changes in work patterns, transport, food production and food sales." The report distinguishes between the vulnerability of the socially and economically disadvantaged (SED) and what is identified in the report as passive obesity. Passive obesity, a term that is not widely used in the literature, is described by Foresight (2007), as obesity that is encouraged by wider environmental conditions, irrespective of volition. Foresight (2007) identifies four key determinants of vulnerability in terms of obesity: primary appetite control in the brain; the strength of dietary habits; level of physical activity; and the psychological ambivalence experienced by individuals in making lifestyle choices. The UK Government asserts that all capable adults are responsible for the personal choices they make (DH, 2011). However they put forward a caveat that individuals do not have total control over their lives or the circumstances in which they live due a wide range of factors that constrain and influence what they do. Vulnerability is the sensibility of individuals who, although intact, are at the same time weak, fragile or biologically ill with an increased predisposition towards supplementary damage (Kottow 2007 cited by Toader et al. 2013; Manning, 2016). Winston (1999) characterizes vulnerable groups as those lacking the ability or power to fully or effectively protect and defend their own interests. Vulnerability in such terms encapsulates fragile integrity and weak consent, and describes individuals or groups having a predisposition to being harmed (Manning, 2016).

Goodin (1985) asserts that through the social attribution of vulnerability, those having a predisposition to obesity, type 2 diabetes and heart disease are often regarded as culpable (Manning, 2016). While culpability implies free choice, conversely vulnerability implies that 
choices are framed by psychological predisposition. These are individuals seen as causing their own health problems, and therefore deserving of societal censure. The lack of awareness, or general acceptance, among the SED, and to a lesser extent individuals, of a more high risk lifestyle means that they are less accessible to policy instruments designed to change food consumption behavior (Manning, 2016). Herrick (2009) concludes that the public rhetoric of some corporations in nudging people towards healthy choices and lifestyles also engenders a sense of culpability and therefore a sense of blame. This drives the consideration that blame and responsibility are interlinked at personal and at corporate levels. Packard et al. (2012) consider that health improvement interventions that are adapted to an individual's personality characteristics, specifically their mental wellbeing, may be more effective. Nevertheless, stigma and discrimination is pervasive and poses numerous consequences for the psychological and physical health of those individuals affected (Puhl and Heuer 2010; Manning, 2016). In fact Toader et al. (2013) argue that vulnerability may be created as a consequence of ill-directed public policies and practices that actually promote stigmatization and marginalization leading to unstable self-esteem. Therefore the literature described would suggest that the prevalence of obesity is a product of personal characteristics and behaviors and ill-directed policy. One view is that the capacity and readiness of consumers to make healthy choices is overstated, and that conversely the power of government and business to determine what we eat is underestimated (Maniates, 2010). Cowburn and Stockley (2005) reviewed 103 published papers, reporting on consumer understanding of food nutrition labeling mainly from northern Europe and North America, They concluded that whilst consumers use simple numerical information to make comparisons between food products, they struggled to understand more complex descriptive information (Manning, 2016). Governmental policy making is often criticized for being paternalistic, for the usurpation of individual responsibility, preventing people from doing what 
they want, or otherwise interfering in consumer decision making, expressly for the purpose of promoting consumer welfare (Manning, 2016 citing Buchanan, 2008).

Higgs (2015) states that social eating norms are perceived standards around what is deemed appropriate consumption in terms of amount of food, portion size (environmental cues), or specific food choices by a defined social group (cultural practices and rules). These standards can develop personal affiliation, a sense of empathy and co-operation, and underpin a concept of public image or impact on self-esteem. Social groups can be typed by factors such as nationality, peer group as already discussed in this paper, family or friendship structures where perceived standards influence actual behavior. Mela (2001:249S) states that difficulties of weight control can reflect problems with "cues and motivations to eat" rather than the pleasure of eating itself. Further, he argues that:

"repeat dieting, high day-to-day fluctuations in intakes, and attempts to enforce highly ridged control over eating all seem to be counter productive to weight control efforts and may disrupt more appropriate food choice behaviors."

Therefore the regulatory: corporate: individual interaction described that occurs at multiple levels can lead to a complex SR landscape.

\section{The social responsibility landscape}

Rayman-Bacchus and Walsh (2016) identify what they describe as a spectrum of reciprocal responsibility for sustainable development (Figure 1). The two dimensional framework works on the consideration of power of influence by industry (weak to strong) and the power of government regulation (weak to strong) with a third dynamic NGO/Civil Society oversight and influence. On one side of the spectrum (Figure 1) government regulation of CR is seen as strong in terms of government regulation and weak in terms of industry influence through to CR as a form of government with strong industry influence and a weak government role.

\section{Take in Figure 1}


Rayman-Bacchus and Walsh suggest that there are a number of pathways citing (Gond et al. 2011) see Manning et al. 2016:

- Corporate responsibility (CR) as a form of government. This approach can mitigate a policy void that is then filled with voluntary agreements rather than regulation. However this can be a challenge when corporate determination of what counts as responsible behavior in practice may not be consistent with the public interest, therefore a strong governance framework is required. This is especially difficult in the area of obesity where corporate bodies could be seen as treating unfairly or stigmatizing specific sectors of their customer base. This approach is unlikely to become policy in the UK.

- Self-governing CR. This strategic tactic does not operate as an alternative to government, rather it is an independent activity where elements of CR which are of operational and strategic importance to the organization are addressed. Again the public interest may be secondary to shareholder value and consolidation of market share and brand value. The development of $\mathrm{CR}$ in this environment means that tactical decision making may well be at odds with operational and strategic requirements. This means that marketing initiatives may on the one hand be developed to meet a CR objective, but on the other be couched in ambiguity so that strategic and operational goals can be met.

- CR facilitated by government. Governments can promote specific social and economic corporate behavior through establishing economic and political incentives such as exemptions, benefits for organizations e.g. planning laws, tax regulation etc. Corporate engagement can be transactional in nature in a "get vs. give" interaction. This has the potential to drive healthier eating e.g. promoting fast food planning 
developments that have healthy options on their menus and cater for a wider range of nutrient rich and energy dense menu items. Again the interaction between consumer sovereignty, and overt processes of choice editing could prove negative for corporations.

- CR as a partnership with government. Corporate investment can deliver social and economic benefits beyond the commercial value of the capital investment. This could be through additional infrastructure or utility investment in the retail complex such as in-store pharmacies or health care centres (Manning et al 2016). However this is a voluntary approach and the retailer may simply chose to build the retail store in a different location where they are able to develop without such infrastructure requirements. Improving access to affordable, good quality foods for those with limited transport would improve health and such concerns must be considered in the planning and regeneration of town centers and residential areas (FPH, 2005). In a time of public sector austerity, this pathway has value at local and national levels of government. This approach has been adopted in the UK.

- CR as regulated by government. This approach leads governments to regulate to ensure corporate compliance e.g. through labor laws, environmental laws, etc. in order to ensure public interest is served. The transactional costs associated with this approach for government will influence the progress of such developments.

Allender et al. (2011) propose more holistic policy strategies such as social marketing, provision of low cost healthy food and taxation of unhealthy. Reducing the sensitivity, by the individual or the community, to coercive measures being adopted by government is a driver of CR mechanisms as previously described. Supporters of "choice editing" by governments and corporate bodies on behalf of the individual advocate shifting "available choices" by removing certain products from the shelves in favor of those that are considered more "healthy" or more 
environmentally responsible (Manning, 2016). This approach impacts, as previously outlined, on the notion of consumer sovereignty by informed food purchasers. However, as has been shown in this paper, governments do play a role in shaping (editing) choices, for example through the development of regulatory mechanisms or voluntary policy initiatives to limit the use of potentially harmful ingredients (e.g. transfats).

The prevalence of obesity and related morbidities when the condition is normalized places it beyond the scope of conventional government interventions. Reflecting on Figure 1, whilst it is indirectly considering the influence of the individual through NGOs and civil society it does not consider the regulatory: corporate: individual interaction as discussed in this paper. Therefore this work proposes that there is a three dimensional dynamic. The concepts outlined in this paper have been drawn together (Figure 2) and demonstrate the complex interaction of the factors described in this paper. When considering what it means to be socially responsible with regard to obesity at the nexus of individual, corporate and government interactions.

\section{Take in Figure 2}

Figure 2 demonstrates that the nexus of policy makers, regulators and corporate organizations in terms of their formalization of corporate policy is complex and multi-layered. Organizations have a responsibility to their shareholders to deliver financial return, but they also have a responsibility to those who purchase and consume their products.

\section{Conclusion}

This paper considers the social trend towards the normalization of obesity as a lens to discuss government's role in supporting businesses to demonstrate and act upon their social responsibilities. Furthermore it questions whether individual and social responsibility are theoretically robust terms for policy purposes, particularly in the case of obesity where the 
condition is now increasingly accepted as being the norm. As demonstrated by Foresight (2007), the ability to consistently access nutritious food has policy implications for urban planning, wage levels, welfare controls, and education and health care provision, at both local and national levels. Foresight (2007) identify five core principles that are critical to the development of a coherent, comprehensive strategy for tackling obesity namely:

1) A system-wide approach, redefining the nation's health as a societal and economic issue;

2) Higher priority for the prevention of health problems, with clearer leadership, accountability, strategy and management structures;

3) Engagement of stakeholders within and outside Government;

4) Long-term, sustained interventions; and

5) Ongoing evaluation and a focus on continuous improvement.

The prevalence of obesity across developed and increasingly in developing economies is a policy problematic that defies conventional policy solutions. Since obesity entered the realm of public discourse, professional and common sense understandings of the condition assumed that the principal causes are gluttony and/or sloth or that individuals are somehow culpable. This is at odds with the notion of vulnerability through a range of social and economic actors that influence an individual's ability to make an informed choice. Moreover, over the last twenty years, obesity as a condition has become normalized. For policy makers, working with a neoliberal paradigm coupled with the politics of austerity, there is an assumption that the issue of obesity responds best to the extension and acceptance of individual responsibility, coupled by the SR interventions of the FDI and government. This paper considers whether individual and SR are theoretically robust terms for implementation purposes, particularly as the condition is now more widely accepted as being the norm. 


\section{References}

Abubakari, A.R., Lauder, W., Agyemang, C., Jones, M., Kirk, A., and Bhopal R.S. (2008), Obesity Review, 9, 297-311

Allender, S., Gleeson, E., Crammond, B., Sacks, G., Lawrence, M., Peeters, A., Loff, B. and Swinburn, B. (2011), Policy change to create supportive environments for physical activity and healthy eating: which options are the most realistic for local government? Health Promotion International, 27(2): 261-273

Amaeshi, K., Osuji, O.K. and Nnodim, P. (2007), Corporate control and accountability in supply chains of multinational corporations: clarifications and managerial implications, No. 46-2007, International Centre for Corporate Social Responsibility, Nottingham University Business School, Nottingham.

Appelhans, B.M., Milliron, B., Woolf, K., Johnson, T.J., Pagoto, S.L., Schneider, K.L., Whited, C.M., Ventrelle, J.C. (2012), Socioeconomic Status, Energy Cost, and Nutrient Content of Supermarket Food Purchases, American Journal of Preventive Medicine, 42(4): $398-402$

Aylott, J., Brown, I., Copeland, R. and Johnson, D. (2008), Tackling Obesities: Foresight Report and Implications for Local Government, Available at: http://www.idea.gov.uk/idk/aio/8268011 [Accessed on 20.07.15]

Becker-Olsen, K.L., Cudmore, B.A. and Hill, R.P. (2006), The impact of perceived corporate social responsibility on consumer behaviour, Journal of Business Research, 59: 46-53.

Benabou, R. and Tirole, J. (2010), Individual and Corporate Social Responsibility, Economica, (2010) 77: 1-19

Buchanan, D.R. (2008), Autonomy, Paternalism and Justice: Ethical Priorities in Public Health, American Journal of Public Health, 98(1): 15-21

Bryden, A. Pettricrew, M., Mays, N., Eastmure, E. and Knai, C. (2013), Health Policy, 110(2): 186-197

Burke, M.A., Heiland, F.W and Nadler, C.M, (2010), From "Overweight" to "About Right": Evidence of a Generational Shift in Body Weight Norms, Obesity, 18: 1226-1234

Cowburn, G., and Stockley, L. (2005), 'Consumer understanding and use of nutrition labelling: a systematic review', Public Health Nutrition, 8(1): 21-28

DH (2011), The Public Health Responsibility Deal. March 2011. Department of Health

Elia, M., and Stratton, R.J. (2009), Calculating the cost of disease related malnutrition in the UK in 2007. In combating malnutrition: recommendations for action. A report from the Advisory Group on Malnutrition led by BAPEN. [M Elia and CA Russell, editors]. Redditch, Worcs.: BAPEN 
Ellulu, M., Abed, Y., Rahmat, A., Ranneh, Y., and Ali, F. (2014) Epidemiology of obesity in developing countries: challenges and prevention, Global Epidemic Obesity, 2 (2), http://dx.doi.org/10.7243/2052-5966-2-2

Foresight (2007), Tackling Obesities: Future choices - Project report, $2^{\text {nd }}$ Edition.

Government Office for Science

Faculty of Public Health (FPH) (2005), Food Poverty and Health, Publication date. May 2005

Frieden, T.R., Dietz, W., and Collins, C. (2010), Reducing Childhood Obesity Through Policy Change: Acting Now to Prevent Obesity, Health Affairs, 29 (3), 357-363

Friedman, M. (1962), Capitalism and Freedom, Chicago: University of Chicago Press

Freijer, K., Tan, S.S, Koopmanschap, M.A., Meijers, J.M.M, Halfens, R.J.G., and Nuijten, M.J.C. (2012), The economic costs of disease related malnutrition, Clinical Nutrition, (2012): $1-6$

Gond, J. P., Kang, N., and Moon, J. (2011), 'The government of self-regulation: On the comparative dynamics of corporate social responsibility', Economy and Society, 40(4): 640671.

Goodin, R.E. (1985), Protecting the Vulnerable: A Reanalysis of Our Social Responsibilities. Chicago, IL: University of Chicago Press, 1985.

Goodman, R.A., Bunnell, R., and Posner, S.F., (2014), What is "community health"?

Examining the meaning of an evolving field in public health? Preventive Medicine, 67, 558561

Hasham, K., C. Haigh and C. Powell (2012). The Irresponsibility Deal?, Children's Food Campaign.

Heath, J. and Norman, W. (2004), Stakeholder Theory, Corporate Governance and Public Management: What can the History of State-Run Enterprises Teach us in the Post-Enron era? Journal of Business Ethics, 53: 247-265

Herrick, C. (2009). "Shifting blame/selling health: corporate social responsibility in the age of obesity." Sociology of Health \& Illness, 31(1): 51-65.

Higgs, S. (2015), Social norms and their influences on eating behaviours, Appetite, 86: 38-44

Jackson, S.E., Johnson, F., Croker, H. and Wardle, J. (2015), Weight perceptions in a population sample of English adolescents: cause for celebration or concern? International Journal of Obesity, 39, 1488-1493

Jones, R. (2005), Finding sources of brand value: developing a stakeholder model of brand equity, Brand Management, 13(1): 10-32. 
Kemper, K.A., Sargent, R.G., Drane, J.W., Valois, R.F., and Hussey, J.R., (1994), Black and White Females' Perceptions of Ideal Body Size and Social Norms, Obesity Research, 2, 117 126

Kottow, M. (2007), Ética de protección: una propuesta de protección bioética. Publisher Bogotá: Universidad Nacional de Colombia. www.worldcat.org

Lake, A. and Townshend, T. (2006). "Obesogenic environments: exploring the built and food environments." The Journal of the Royal Society for the Promotion of Health 126(6): 262267.

Lake, A. A., T. G. Townshend and S. Alvanides, Eds. (2010). Obesogenic Environments: Complexities, Perceptions and Objectives Measures. Oxford, Wiley-Blackwell.

Lally, P. Bartle, N. and Wardle J. (2011), Social norms and diet in adolescents, Appetite, 57: 623-627

Lebel, J. (2003), Health: An Ecosystem Approach. International Development Research Centre, Ottawa.

Lee, K. Conklin, M., Cranage, D.A., and Lee, S. (2014), The role of perceived corporate social responsibility on providing healthful foods and nutrition with health-consciousness as a moderator, International Journal of Hospitality Management, 27: 29-37

MacQueen, K.M., McClellan, E., Metzger, D.S., Kegeles, S., Strauss, R.P., Scotti, R., Blanchard, L., and Trotter II, R.T. (2001. What is community? An evidence-based definition for participatory public health, American Journal of Public Health, 91, 1929-1938.

Maniates, M. (2010), Editing Out Unsustainable Behavior, in Worldwatch Institute's State of the World 2010: Transforming Cultures, From Consumerism to Sustainability, Available at http://blogs.worldwatch.org/transformingcultures/wp-content/uploads/2009/11/SOW2010PreviewVersion.pdf [Accessed on 02.01.15]

Manning L. (2016), Health and well-being vulnerability of the socio-economically disadvantaged: the role of food, in Corporate Responsibility \& Sustainable Development: the nexus of private and public interests, edited by Lez Rayman-Bacchus and Philip Walsh, Routledge.

Manning, L., Kelly, J.T., Stanner, S. (2016) Enabling UK consumption of fruit and vegetables. Report prepared for the National Farmers Union, Available at: https://www.rau.ac.uk/sites/files/rau/NFU\%20Report\%20complete.pdf [Accessed on $14 / 09 / 16]$

Manning L., and Baines R.N. (2004), Globalisation. A study of the poultry meat supply chain, British Food Journal, 106(10/11): 819-836.

Mela, D.J. (2001), Determinants of Food Choice: Relationships with Obesity and Weight Control, Obesity Research, 9(4): 249S-255S 
OEDC (2014), Obesity Update, OEDC Directorate for Employment, Labour and Social Affairs, Available at: http://www.oecd.org/health/Obesity-Update-2014.pdf [Accessed on 18th July 2015]

Packard, C.J., Cavanagh, J., McLean, J.S, McConnachie, A., Messow, C.M., Batty, G.D., Burns, H., Deans, K.A., Sattar, N., Shiels, P.G, Velupillai, Y.N, Tannahill, C., and Millar, K. (2012), Interaction of personality traits with social deprivation in determining mental wellbeing and health behaviours. Journal of Public Health, May, 2 (2012) 1-10

Panjwani, C. and M. Caraher (2014). "The Public Health Responsibility Deal: Brokering a deal for public health, but on whose terms?" Health Policy 114(2): 163-173.

Petticrew, M., Eastmure, E., Mays, N., Knai, C., Durand, M.A. and Nolte, E. (2013), The Public Health Responsibility Deal: how should such a complex public health policy be evaluated? Journal of Public Health, 35(4): 495-501

Prentice, A.M. and Jebb, S.A., (1995), Obesity in Britain: gluttony or sloth? British Medical Journal, 12:311(7002): 437-9

Puhl, R.M., and Heuer, C.A. (2010), Obesity Stigma: important Considerations for Public Health, American Journal of Public Health, 100(6): 1013-1028

Rayman-Bacchus, L. and Walsh, P. (2016), Health and well-being vulnerability of the socioeconomically disadvantaged: the role of food, in Corporate Responsibility \& Sustainable Development: the nexus of private and public interests, Routledge.

Spence, L. and Bourlakis, M. (2009), The evolution from corporate social responsibility to supply chain responsibility: the case of Waitrose, Supply Chain Management: An International Journal, 14 (4): 291-302.

Stigliz, J.E. (2006), Making Globalization Work, Allen Lane, London.

Toader, E., Damir, D. and Toader, T. (2013), Vulnerabilities in the Medical Care, Procedia Social and Behavioral Sciences, 92: 936 - 940

Wang, Y., Xue, H. Chen, H. and Igusa, T. (2014), Examining social norm impacts on obesity and eating behaviors among US school children based on agent-based model , BMC Public Health, 14: 923

Winston, M.E. (1999), "Indivisibility and Interdependence of Human Rights". Text of public lecture, as presented at the Nebraska Union, University of Nebraska- Lincoln, Lincoln, Nebraska, USA September 3, 1999

WCRFI (2015) (World Cancer Research Fund International) WRCF International Nourishing Framework - Restrict food advertising and other forms of commercial promotion, Available at: http://www.wcrf.org/int/policy/nourishing-framework/restrict-food-marketing [Accessed on $14 / 09 / 2016$ ] 


\begin{tabular}{|c|c|}
\hline COUNTRY & PUBLIC HEALTH INITIATIVES \\
\hline Chile & $\begin{array}{l}\text { Chile's law on food labelling and advertising, introduced in 2012, aims at limiting access to potentially unhealthy food for children, and covers advertisement on media, point-of-sale } \\
\text { marketing, promotions and the school environment. The law is currently being implemented. In } 2015 \text { the Chilean authority approved the regulatory norms required for the law's } \\
\text { implementation }\end{array}$ \\
\hline Denmark & $\begin{array}{l}\text { The tax on saturated fat introduced in Denmark in October } 2011 \text { reduced the consumption of the taxed products by } 10 \% \text { to } 15 \% \text { in the first nine months, with demand partially shifting } \\
\text { from high- price supermarket to discount stores. The revenues raised between November } 2011 \text { and January } 2012 \text { were more than } 96 \% \text { of those originally forecasted. However, the tax was } \\
\text { abolished in November 2012, amidst political controversy and lobby pressures. The Code of Responsible Food Marketing Communication was issued by the Forum of Responsible Food } \\
\text { Marketing Communication, a cooperation between Danish industry organisations of the food and beverage, retail and media sectors. The Code is a voluntary, self-regulatory initiative } \\
\text { effective since January 2008, applicable to food and beverage marketing to children aged } 13 \text { and under via media outlets (TV, radio, internet, SMS, newspapers, comic books). The Code } \\
\text { sets guideline limits for salt, sugar and fat content in ten food categories. It is recommended that food products exceeding these limits should not be marketed to children. Food } \\
\text { manufacturers themselves determine if their products are suitable for marketing to children. Compliance is checked by the secretariat of the Forum. The Danish government follows the } \\
\text { results of the Code, and annual status meetings are held between the Danish Veterinary and Food Administration and the Forum. }\end{array}$ \\
\hline France & $\begin{array}{l}\text { Tax on soft drinks implemented in France. The degree to which the tax was passed on to consumers varied from } 60 \% \text { for fruit drinks to } 100 \% \text { for carbonated drinks. All television } \\
\text { advertising (targeted at children or adults) for processed food and drinks, or food and drinks containing added fats, sweeteners and/or salt, must be accompanied by a message on the } \\
\text { principles of dietary education as approved by the National Institute of Health Education. The messages were defined by a } 2007 \text { Decree: "For your health, eat at least five fruits and } \\
\text { vegetables a day"; "For your health, exercise regularly"; "For your health, avoid eating too many foods that are high in fat, sugar or salt"; "For your health, avoid snacking between } \\
\text { meals". }\end{array}$ \\
\hline Hungary & $\begin{array}{l}\text { The Public Health Tax on Food Products introduced in Hungary in } 2011 \text { led to a } 29 \% \text { price increase, and a } 27 \% \text { drop in sales, for the taxed products. It is estimated that } 40 \% \text { of food } \\
\text { manufacturers reformulated their products by reducing or eliminating the ingredients associated with the tax although there are some questions on validity of the results. }\end{array}$ \\
\hline Iceland & $\begin{array}{l}\text { Iceland passed a law banning advertising in programmes aimed at children aged less than } 12 \text { in } 2013 \text {. Advertising, sponsorship, teleshopping and product placement of foods high in fats, } \\
\text { sugars and salt, as defined by a nutrient profiling model, are prohibited during children's TV and radio programmes where over } 50 \% \text { of the audience are under } 18 \text { years old (Children's } \\
\text { Commercial Communications Code, } 2013 \text { revision). In addition, there is an overall limit on advertising of foods high in fats, sugars and salt adverts at any time of day to no more than } \\
25 \% \text { of sold advertising time and to only one in four advertisements. Remaining advertising targeted at children under the age of } 13 \text { must not include nutrient or health claims or include } \\
\text { licensed characters. }\end{array}$ \\
\hline Iran & $\begin{array}{l}\text { Broadcast advertising of soft drinks has been prohibited since 2004. In 2014, in the context of the Iranian Fifth Five-Year Development Plan (2011-2015), the Ministry of Health and } \\
\text { Medical Education prepared a list of } 24 \text { food items to be prohibited from advertising in all media. The list has been sent to the Commerce, Industry and Finance ministries for approval. }\end{array}$ \\
\hline Ireland & $\begin{array}{l}\text { In 2012, the Irish Department of Health estimated that a } 10 \% \text { tax on sugar sweetened beverages (SSBs) would reduce calorie intake by } 2.1 \mathrm{Kcal} \text { per week, on average (with a greater } \\
\text { reduction in young people), and translate into } 10000 \text { fewer obese adults. Based on this evidence, the Department of Health proposed a } 20 \% \text { tax on SSBs during the discussion of the } 2014 \\
\text { budget, but the tax has not been adopted. }\end{array}$ \\
\hline Japan & $\begin{array}{l}\text { In Japan, a programme of health examinations to identify people at risk for the metabolic syndrome and prevent its chronic disease consequences has been in place since } 2008 \text {. Starting in } \\
2013 \text {, insurers' contributions to cover care for the elderly will be linked with insurers' achievement of coverage targets for such health examinations. }\end{array}$ \\
\hline Mexico & $\begin{array}{l}\text { Mexico has adopted one of the most comprehensive government programs. A National Strategy for the Prevention and Control of Overweight, Obesity and Diabetes was launched in the } \\
\text { second half of 2013. The policy has three pillars: improved public health and surveillance; better medical care for people with chronic diseases; regulation and fiscal measures. During the } \\
\text { first phase of the strategy, the Mexican authorities have launched a media campaign aimed at raising public awareness of obesity and related chronic diseases. At the same time, a number } \\
\text { of states started piloting the use of new technologies and non-economic incentives for physicians with the objective of increasing uptake and compliance to medical prescriptions for } \\
\text { people with diabetes, high blood pressure and other related chronic diseases. Mexico is also reinforcing its regulatory framework on food advertising to children, labelling of processed } \\
\text { food, availability of food in schools and taxation of unhealthy food. In January 2014, Mexico implemented a new tax levied at a rate of } 8 \% \text { on food with an energy content exceeding } 275 \\
\text { Kcal per } 100 \mathrm{~g} \text {, and } 1 \text { peso (EUR 0.06) per litre on sugar-sweetened beverages. Revenues are expected to support public health programs, although they are not formally earmarked. The } \\
\text { tax was met with strong opposition by the industries concerned, but was relatively well accepted by the Mexican population. New regulations were introduced to protect children from } \\
\text { exposure to advertising of potentially unhealthy foods. They ban the advertising of potentially unhealthy foods, on radio and TV, during hours in which children are a significant } \\
\text { component of the audience (between 07:00 and 19:30 during week- ends, and between 14:30 and 19:30 during week days) exceptions are programmes such as sport events. Restrictions } \\
\text { will apply in cinemas showing movies aimed at children, but do not cover billboards and the Internet. }\end{array}$ \\
\hline
\end{tabular}




\begin{tabular}{|l|l|}
\hline Norway & $\begin{array}{l}\text { The government already restricts all broadcast advertising to children through legislation in Norway (Broadcasting Act 1992). A voluntary initiative agreed in 2013 calls on industry to } \\
\text { follow standards (set largely by government) on a further range of } \\
\text { communications channels. It applies to marketing to children under the age of 13. In 2011, the Ministry of Health signed a Memorandum of Cooperation with the Federation of Food } \\
\text { Enterprises and the Association of Soft Drink Companies to encourage companies not to advertise soft drinks to children aged 12 and under. The Memorandum applies to soft drink } \\
\text { marketing in movie theatres and on TV if the audience consists of at least 50\% children, and includes marketing activities on the internet and in the press. }\end{array}$ \\
\hline UK & $\begin{array}{l}\text { Advertising and product placement of foods high in fats, sugars and salt, as defined by a nutrient profiling model, is prohibited during TV and radio programmes that have 20\% or more } \\
\text { viewers under } 16 \text { years old relative to the general viewing population (includes sponsorship of TV programmes). The restrictions came into force in February 2007, with a phased } \\
\text { implementation by advertisers by end of 2008. }\end{array}$ \\
\hline US & $\begin{array}{l}\text { The US government has proposed to overhaul food nutrition labels, in particular to revise serving sizes, display calories more prominently, and include information on added sugars. If } \\
\text { approved, food manufacturers will have two years to implement the new labels. A further multi-stakeholder example is the DrinkUp campaign promoted in 2013 by the Partnership for a } \\
\text { Healthier America, chaired by the First Lady of the United States, and including a large number of business and civil society partners. The campaign had a scientific data-drive design, } \\
\text { and early monitoring data show it has had some success in increasing water drinking. }\end{array}$ \\
\hline
\end{tabular}


Table 2: Core commitments and supporting pledges associated with the UK Public Health Responsibility Deal (Source: DH, 2011)

\begin{tabular}{|c|c|}
\hline $\begin{array}{l}\text { The core commitments } \\
\text { The business community, voluntary sector and NGOs have } \\
\text { already done a great deal to help people achieve a healthier } \\
\text { diet, increase their levels of physical activity, drink sensibly } \\
\text { and understand the health risks of their lifestyle choices. } \\
\text { Signatories to the Public Health Responsibility Deal will work } \\
\text { in support of the following core commitments in relation to } \\
\text { their customers and staff, where relevant. } \\
\text { - We recognize that we have a vital role to play in } \\
\text { improving people's health. } \\
\text { - We will encourage and enable people to adopt a } \\
\text { healthier diet. } \\
\text { We will foster a culture of responsible drinking, } \\
\text { which will help people to drink within guidelines. } \\
\text { We will encourage and assist people to become more } \\
\text { physically active. } \\
\text { We will actively support our workforce to lead } \\
\text { healthier lives. }\end{array}$ & $\begin{array}{l}\text { The supporting pledges } \\
\text { a) We will support the approach of the Public } \\
\text { Health Responsibility Deal and encourage other } \\
\text { organizations to sign up. } \\
\text { b) We acknowledge that the Deal's strength comes } \\
\text { from organizations of different types across varying } \\
\text { sectors working together to improve people's } \\
\text { health. } \\
\text { c) We will contribute to the monitoring and } \\
\text { evaluation of progress against the pledges. } \\
\text { d) Where we offer people information to help make } \\
\text { healthier choices, we will use messages which are } \\
\text { consistent with Government public health advice. } \\
\text { e) We will broaden and deepen the impact of the } \\
\text { Public Health Responsibility Deal by working to } \\
\text { develop further pledges in support of the five core } \\
\text { commitments. }\end{array}$ \\
\hline
\end{tabular}

Table 3. Food pledges and signatory associations (Source: https://responsibilitydeal.dh.gov.uk/pledges/)

\begin{tabular}{|c|c|c|}
\hline & Pledge & Number of Signatories \\
\hline F1 & Out of Home Energy (kJ/kcal) Labeling & 45 \\
\hline F2 & Salt reduction (pledge now closed) & 78 \\
\hline F3(a) & Non use of Artificial Trans Fats & 90 \\
\hline$\frac{F 5(b)}{F 4}$ & $\begin{array}{l}\text { Artificial Trans Fat Removal } \\
\text { Calorie Reduction }\end{array}$ & $\frac{11}{43}$ \\
\hline $\begin{array}{l}\text { F5 } \\
\text { F5(a) } \\
\text { F5(b) } \\
\text { F5(c). }\end{array}$ & $\begin{array}{l}\text { Salt Catering } \\
\text { Salt Catering: Training and Kitchen Practice } \\
\text { Salt Catering: Reformulation of products as purchased by the customer } \\
\text { Salt Catering: procurement }\end{array}$ & $\begin{array}{l}15 \\
10 \\
9\end{array}$ \\
\hline F6 & Fruit and vegetables & 48 \\
\hline $\begin{array}{l}\text { F7(a) } \\
\text { F7(b) }\end{array}$ & $\begin{array}{l}\text { Front of Pack Nutrition Labeling } \\
\text { Front of Pack Nutrition Labeling }\end{array}$ & $\begin{array}{l}23 \\
17\end{array}$ \\
\hline F8 & Saturated Fat Reduction & 18 \\
\hline F9 & Salt Reduction 2017 & 39 \\
\hline F10 & Out of Home maximum per serving salt targets & 7 \\
\hline
\end{tabular}


Table 4. Signatories for the calorie reduction pledge categorized by type (Source: https://responsibilitydeal.dh.gov.uk/pledges/)

\begin{tabular}{|l|l|l|}
\hline Category & \multicolumn{1}{|c|}{ Organization } & $\begin{array}{l}\text { Number of } \\
\text { Signatories }\end{array}$ \\
\hline $\begin{array}{l}\text { Catering, Food Service } \\
\text { and Facilities } \\
\text { Management }\end{array}$ & $\begin{array}{l}\text { Amadeus; Aramark; CH \& Co Catering Limited; Compass Group UK \& } \\
\text { Ireland; Dine Contract Catering Ltd; Holroyd Howe; JD Wetherspoon } \\
\text { Plc; Lexington Catering; Sodexo; Starbucks Coffee Company; Subway } \\
\text { International B.V;; Whitbread Group Plc; }\end{array}$ & 12 \\
\hline Leisure & $\begin{array}{l}\text { Empire Cinemas Ltd; Pepsi MAX Cinema Partnership; Vue } \\
\text { Entertainment }\end{array}$ & 3 \\
\hline $\begin{array}{l}\text { Manufacturer: Chilled } \\
\text { food products }\end{array}$ & Kerry Foods & 1 \\
\hline $\begin{array}{l}\text { Manufacturer: } \\
\text { Dairy-based products }\end{array}$ & Dairy Crest Ltd; & 1 \\
\hline Manufacturer: Drinks & $\begin{array}{l}\text { A.G. Barr PLC; Britvic Soft Drinks; Coca-Cola Great Britain; Feel } \\
\text { Good Drinks; Lucozade Ribena Suntory; Nichols Plc; PepsiCo UK \& } \\
\text { Ireland; The SHS Group Drinks Division }\end{array}$ & 8 \\
\hline $\begin{array}{l}\text { Manufacturer: Multiple } \\
\text { products }\end{array}$ & $\begin{array}{l}\text { Mars (UK); Mondelez International; Nestle UK; Premier Foods; } \\
\text { Unilever UK Ltd; }\end{array}$ & 5 \\
\hline $\begin{array}{l}\text { Manufacturer: } \\
\text { Ready Meals and Snacks }\end{array}$ & $\begin{array}{l}\text { Authentic Food Company; Burton's Foods Ltd; Seabrook Crisps Ltd; } \\
\text { United Biscuits; }\end{array}$ & 4 \\
\hline Retailer & $\begin{array}{l}\text { ALDI Stores Ltd; ASDA; Co-operative Group (The); Marks and } \\
\text { Spencer: Morrisons (Wm Morrison Supermarkets Plc); Sainsbury's } \\
\text { Supermarkets Ltd; Tesco PLC; Waitrose; Note: Lidl has signed up to } \\
\text { other pledges but not this particular one. }\end{array}$ & 8 \\
\hline Dairy (UK) & 1 \\
\hline Total & \begin{tabular}{l} 
\\
\hline
\end{tabular} & \\
\hline
\end{tabular}


Table 5. Food Serves RD pledges by organization (Source: $\underline{\text { https://responsibilitydeal.dh.gov.uk/pledges/) }}$

\begin{tabular}{|c|c|c|c|c|c|c|c|c|c|c|c|c|}
\hline \multirow[t]{2}{*}{ Pledge } & F1 & $\mathbf{F 2}$ & F3(a) & F3(b) & $\mathbf{F 4}$ & F5(a) & F5(b) & F5(c). & F6 & F8 & F9 & F10 \\
\hline & 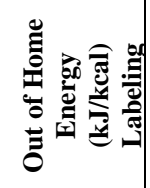 & 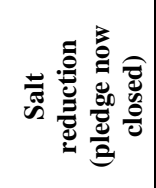 & 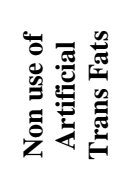 & 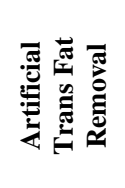 & ฮั & 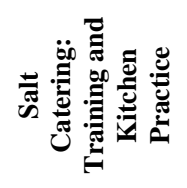 & 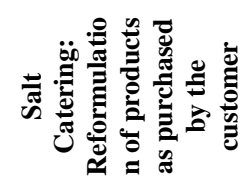 & 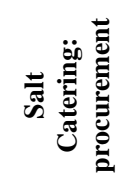 & 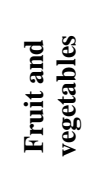 & 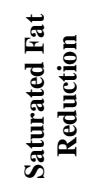 & 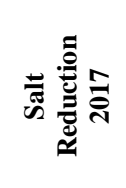 & 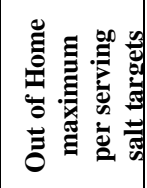 \\
\hline Amadeus & & & & & $\mathrm{X}$ & $\mathrm{X}$ & & & & & & \\
\hline Aramark & $\mathrm{X}$ & & $\mathrm{X}$ & & $\mathrm{X}$ & $\mathrm{X}$ & & $\mathrm{X}$ & $\mathrm{X}$ & & & \\
\hline Artizian & $\mathrm{X}$ & $\mathrm{X}$ & & $\mathrm{X}$ & & & & & & & & \\
\hline Bartlett Mitchell & $\mathrm{X}$ & $\mathrm{X}$ & $\mathrm{X}$ & & & & & & $\mathrm{X}$ & & & \\
\hline BaxterStorey & & & $\mathrm{X}$ & & & $\mathrm{X}$ & & $\mathrm{X}$ & & & & \\
\hline Bella Italia Restaurants & & $\mathrm{X}$ & $\mathrm{X}$ & & & & & & & & $\mathrm{X}$ & \\
\hline Bidvest 3663 & & & $\mathrm{X}$ & & & & & $\mathrm{X}$ & $\mathrm{X}$ & & & \\
\hline Burger King UK Ltd & $\mathrm{X}$ & & $\mathrm{X}$ & & & & & & & & & \\
\hline Café Rouge Restaurants Ltd & & $\mathrm{X}$ & $\mathrm{X}$ & & & & & & & & $\mathrm{X}$ & \\
\hline Caffé Nero Group Ltd & & & $\mathrm{X}$ & & & & & & & & & \\
\hline CH\&Co Catering Ltd & & $\mathrm{X}$ & $\mathrm{X}$ & & $\mathrm{X}$ & & & & $\mathrm{X}$ & $\mathrm{X}$ & $\mathrm{X}$ & \\
\hline Compass Group UK \& Ireland & $\mathrm{X}$ & $\mathrm{X}$ & $\mathrm{X}$ & & $\mathrm{X}$ & $\mathrm{X}$ & & & $\mathrm{X}$ & $\mathrm{X}$ & $\mathrm{X}$ & $\mathrm{X}$ \\
\hline Domino’s Pizza Group & $\mathrm{X}$ & & $\mathrm{X}$ & & & & $\mathrm{X}$ & & & & & \\
\hline EAT & $\mathrm{X}$ & $\mathrm{X}$ & $\mathrm{X}$ & & & & & & & & $\mathrm{X}$ & \\
\hline Ed's Easy Diner & & $\mathrm{X}$ & $\mathrm{X}$ & & & & & & & & & \\
\hline Harvester Restaurants & $\mathrm{X}$ & & & & & & & & & & & \\
\hline Jamie's Italian & & & & & & & & $\mathrm{X}$ & & & & $\mathrm{X}$ \\
\hline JD Weatherspoons & & $\mathrm{X}$ & & & $\mathrm{X}$ & & $\mathrm{X}$ & & & & $\mathrm{X}$ & \\
\hline KFC UKI & $\mathrm{X}$ & & $\mathrm{X}$ & & & $\mathrm{X}$ & $\mathrm{X}$ & & & & & \\
\hline Lexington Catering & & $\mathrm{X}$ & & $\mathrm{X}$ & $\mathrm{X}$ & $\mathrm{X}$ & & & & & & \\
\hline Marston's PLC & & $\mathrm{X}$ & $\mathrm{X}$ & & & & & & & & & \\
\hline $\begin{array}{c}\text { McDonalds } \\
\text { Restaurants Ltd }\end{array}$ & $\mathrm{X}$ & & $\mathrm{X}$ & & & & & $\mathrm{X}$ & & & & \\
\hline Midshire Catering & & & & & & $\mathrm{X}$ & & & & & & \\
\hline Mitchells \& Butler & & & $\mathrm{X}$ & & & $\mathrm{X}$ & $\mathrm{X}$ & & & & & \\
\hline Olive Catering Services & & $\mathrm{X}$ & $\mathrm{X}$ & & & $\mathrm{X}$ & & & & & & \\
\hline Papa John’s GB Ltd & & & $\mathrm{X}$ & & & & & & & & & \\
\hline Pizza Express & & $\mathrm{X}$ & $\mathrm{X}$ & & & & & & & & & \\
\hline Pizza Hut & $\mathrm{X}$ & & $\mathrm{X}$ & & & & & & & & & \\
\hline Pret A Manger & $\mathrm{X}$ & $\mathrm{X}$ & $\mathrm{X}$ & & & & $\mathrm{X}$ & & & & $\mathrm{X}$ & \\
\hline Restaurant Group & & & $\mathrm{X}$ & & & & & $\mathrm{X}$ & $\mathrm{X}$ & & $\mathrm{X}$ & \\
\hline
\end{tabular}




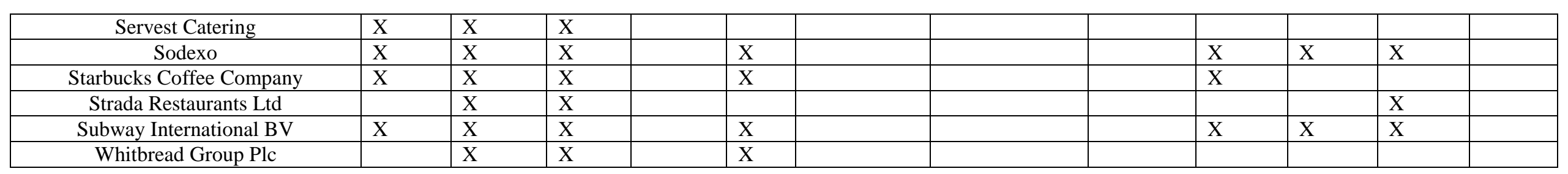




\section{Gov regulation}

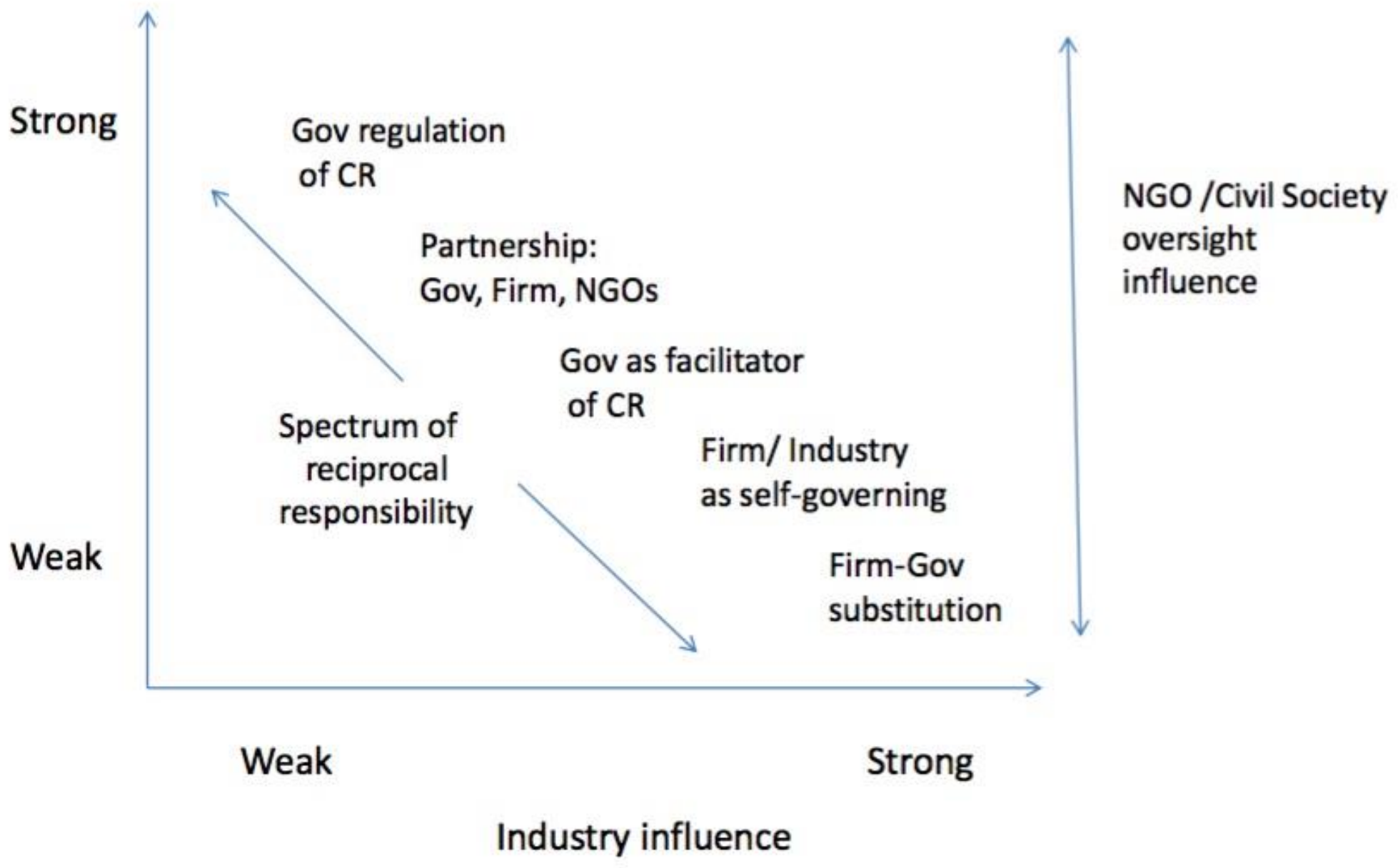

Figure 1: Spectrum of responsibility for sustainable development (Source: Rayman-Bacchus, and Walsh, 2016) 


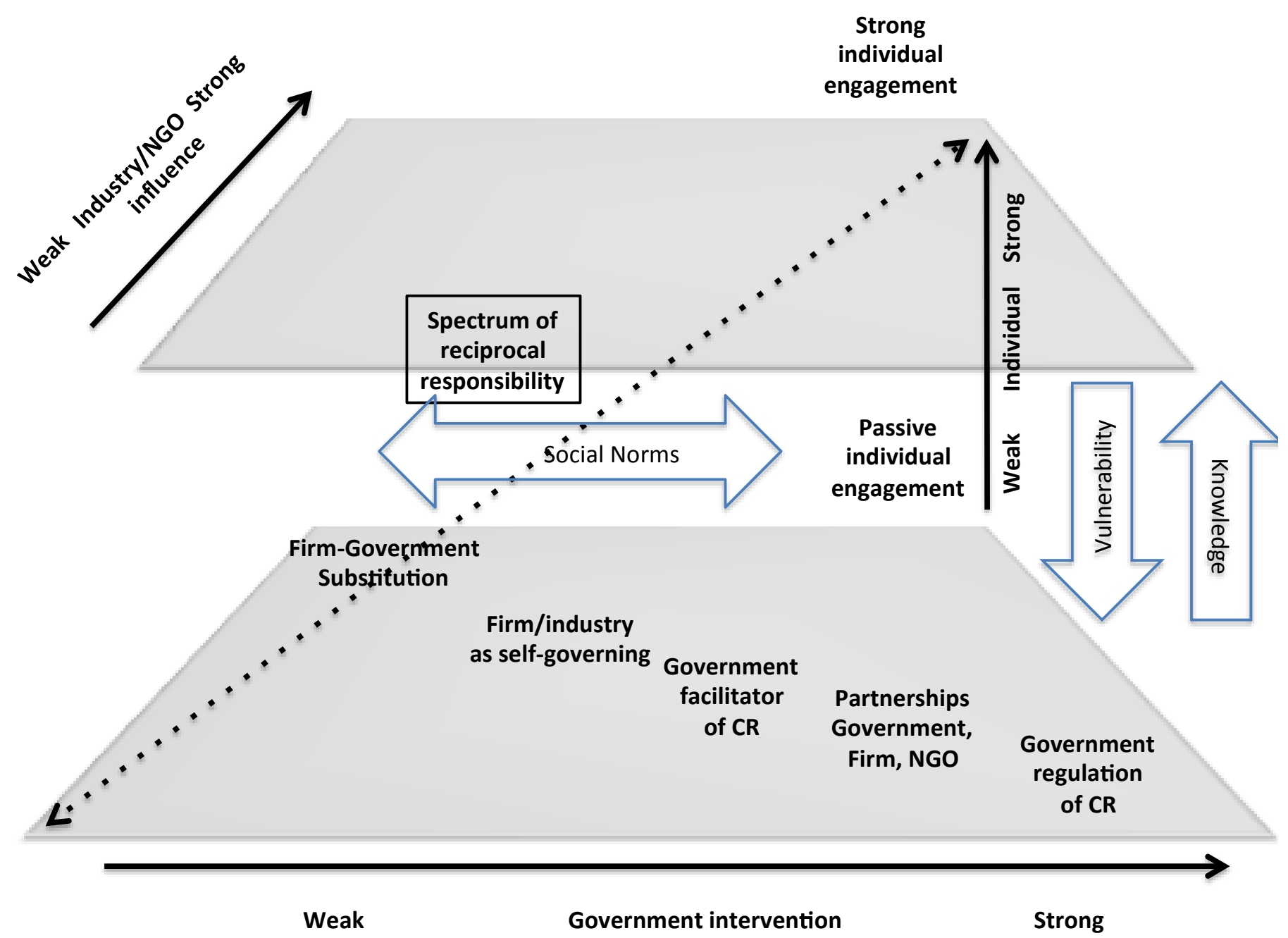

Figure 2: Obesity: spectrum of reciprocal responsibility (Adapted from Rayman-Bacchus, and Walsh 2016) 